\title{
Pelatihan Keterampilan Menolak dan Asertivitas Pada Remaja Selama Pandemi COVID-19
}

\author{
Refusal Skill and Assertiveness Training for Adolescents during \\ the COVID-19 Pandemic
}

\author{
Rika Kristina, Luh Surini Yulia Savitri \\ Fakultas Psikologi, Universitas Indonesia, Depok, Indonesia
}

\begin{abstract}
Adolescents are prone to receive negative peer pressure. One of the main causes is the need of social acceptance. The aim of this study is to improve adolescents' refusal skill and assertiveness to avoid negative peer pressure through experiential learning approach. Online training is carried out due to the COVID-19 pandemic, which makes face-to-face activities need to be restricted. The subjects of this study are 5 female students from three different schools in Jakarta, who were selected using purposive sampling method with Peer Pressure Inventory. Data were collected quantitatively using two different questionnaires which measure refusal skill, and assertiveness separatedly, while qualitative data were collected through observation and role-play activity. Wilcoxon signed ranked test was used to analyze the quantitative data, while the qualitative data were analyzed descriptively. The results show the significant increase of assertiveness among participants after joining the training, but not with their refusal skills. This may be caused by the limited time of practicing the refusal skill in real context. Overall, online refusal skill and assertiveness training is likely to be given amid the COVID-19 pandemic.
\end{abstract}

Keywords: Adolescents, assertiveness, peer pressure, refusal skill

\begin{abstract}
Abstrak: Remaja rentan menerima dan terpengaruh oleh tekanan negatif dari teman sebaya. Salah satu penyebab utama adalah adanya kebutuhan untuk mendapat penerimaan dari lingkungan. Tujuan penelitian ini adalah meningkatkan keterampilan menolak dan asertivitas remaja agar terhindar dari tekanan negatif teman sebaya. dengan pendekatan experiential learning. Pelatihan daring dilakukan karena adanya pandemi COVID-19 yang membuat seluruh kegiatan tatap muka perlu dihindari. Subjek dalam pelatihan ini adalah 5 remaja perempuan dari tiga sekolah di Jakarta, yang dipilih dengan metode purposive sampling menggunakan Peer Pressure Inventory. Data kuantitatif diperoleh melalui dua kuesioner berbeda untuk mengukur keterampilan menolak dan asertivitas secara terpisah. Data kualitatif diperoleh melalui observasi dan aktivitas role-play. Wilcoxon signed ranked test digunakan untuk menganalisis data kuantitatif, sedangkan data kualitatif dianalisis secara deskriptif. Hasil menunjukkan adanya peningkatan yang signifikan pada tingkat asertivitas partisipan, namun tidak dengan keterampilan menolaknya. Hal ini dapat dipengaruhi oleh keterbatasan kesempatan mempraktikkan keterampilan menolak dalam konteks yang sesungguhnya. Secara keseluruhan, pelatihan keterampilan menolak dan asertivitas secara daring sangat mungkin diberikan pada masa pandemi COVID-19.
\end{abstract}

Kata Kunci: Asertivitas, keterampilan menolak, remaja, tekanan teman sebaya

Korespondensi tentang artikel ini dapat dialamatkan kepada Rika Kristina melalui email: rikakristinaa@gmail.com 
Hubungan pertemanan merupakan salah satu faktor paling menonjol yang dapat mempengaruhi remaja (Farrell et al., 2017). Kehadiran sekelompok teman dapat menjadi faktor penguat sekaligus faktor resiko yang dapat memengaruhi remaja untuk menampilkan perilaku negatif. Penyebabnya adalah remaja sedang berada dalam masa pencarian identitas yang membuat interaksi dengan teman sebaya menjadi semakin intens (Brownet et al., 2008). Pada tahap ini, mereka akan mulai menghindari interaksi dengan keluarga dan mulai membangun hubungan semakin intim dengan teman sebaya (Yüksel-Şahin, 2015).

Bagi remaja, konteks sosial memegang peranan yang penting karena dapat mendorong mereka untuk memeroleh penerimaan, stasus sosial, dan perhatian (Forbes \& Dahl, 2010). Hal-hal tersebut menjadi kebutuhan utama yang berperan menentukan perilaku remaja. Oleh karena itu, perilaku yang ditunjukkan oleh remaja biasanya identik dengan perilaku suka mencari sensasi, mudah terpengaruh, dan cenderung mengabaikan dampak dari tindakan mereka (Forbes \& Dahl, 2010). Jika tidak berhatihati, kondisi ini dapat membuat remaja rentan terjerumus pada pergaulan yang buruk.

Badan Pusat Statistik (BPS, 2012) melaporkan hasil survei kesehatan reproduksi remaja dengan sampel sebanyak 8.902 wanita dan 10.980 pria usia remaja dan belum menikah. Hasilnya menunjukkan bahwa perilaku merokok, minum-minuman beralkohol, dan penggunaan obat terlarang yang ada di Indonesia menunjukkan hasil yang cukup tinggi. Data merokok pada wanita ditemukan sebanyak 8,9 persen dan 3,5 persen meminum alkohol. Untuk pria, didapatkan 74,4 persen merokok dan 30,2 persen meminum alkohol, sedangkan penggunaan obat-obatan terlarang jauh lebih terbatas, yaitu kurang dari 1 persen untuk wanita dan 2,8 persen untuk pria. Data tersebut menunjukkan bahwa remaja sangat rentan untuk melakukan berbagai kenakalan atau perilaku menyimpang.

Kenakalan remaja dapat didefinisikan sebagai perilaku yang dilakukan oleh individu berusia remaja, yang tergolong melanggar peraturan dan hukum (Murray \& Farrington, 2010). Menurut Dodge et al. (2006), kenakalan remaja biasanya timbul karena adanya tekanan negatif oleh teman sebaya. Penelitian oleh Sullivan (2006) menunjukkan bahwa tekanan negatif oleh teman sebaya ditemukan sebagai prediktor kuat dari kemunculan kenakalan remaja. Masalah perilaku akan semakin tinggi pada individu yang berasosiasi dengan kelompok teman sebaya yang juga melakukan perilaku yang sama. Tekanan teman sebaya membuat remaja melakukan konformitas kepada suatu kelompok (Loke et al., 2016). Kelompok tersebut bisa berupa geng, clique, maupun peer group. Jika terdapat satu anggota kelompok saja yang menunjukkan perilaku menyimpang, secara tidak langsung hal itu akan dapat mempengaruhi seluruh anggota kelompok yang lain, sehingga kemungkinan anggota lain untuk melakukan hal yang sama akan meningkat (Dishion, Andrews, \& Crosby, 1995).

Tekanan teman sebaya terjadi utamanya ketika remaja berinteraksi secara langsung di sekolah. Akan tetapi, tidak dipungkiri bahwa tekanan teman sebaya juga terjadi ketika remaja harus belajar dari rumah selama pandemi COVID-19 berlangsung. Data yang diterbitkan pemerintah Indonesia per 25 April 2021 menunjukkan 1,641,194 orang terinfeksi virus dengan 1,496,126 sembuh dan 44,594 korban meninggal dunia (CNBC Indonesia, 2021). Dengan tingginya angka penyebaran COVID-19, pemerintah menerbitkan beberapa kebijakan, di antaranya adalah penerapan pembatasan sosial berskala besar (PSBB) (Saputri \& Taher, 2020).

Kebijakan berkenaan dengan pandemi COVID-19 tersebut turut mempengaruhi aspek sosial dan interaksi sosial yang ada di masyarakat, tidak terkecuali bagi para pelajar. Terdapat beragam perubahan yang perlu dihadapi seperti belajar secara daring, tidak bisa bermain di tempat terbuka, tidak melakukan kontak fisik, harus menggunakan masker, serta menghindari kerumuman. 
Penting bagi remaja untuk mematuhi anjuran pemerintah karena seringkali anak atau remaja yang terjangkit COVID-19 tidak menampilkan gejala, padahal mereka membawa virus tersebut (carrier). Sementara itu, remaja rentan dipengaruhi oleh teman sebaya untuk bersama-sama menampilkan perilaku yang serupa dalam agar dapat diterima kelompok (Steinberg, 2008). Hal ini dapat berpotensi menjadi konflik saat remaja mendapat tekanan negatif dari teman sebaya yang bertentangan dengan kebijakan pemerintah selama PSBB. Misalnya, diajak berkumpul ke tempat ramai, berkunjung ke rumah teman, atau menyebarkan berita tidak jelas terkait COVID-19. Wilson et al. (2020) menyatakan bahwa tingkat penyebaran virus semakin tinggi karena pemuda sulit menghindari pertemuan sosial dan terpengaruh untuk tidak menggunakan masker ketika berkumpul.

Konformitas individu terhadap perilaku yang ditampilkan oleh teman sebaya meningkat secara tajam di usia 10 sampai 15 tahun (Brown et al., 1986; Hall et al., 2011). Sejalan dengan itu, prevalensi perilaku kenakalan remaja mencapai puncaknya di rentang usia remaja madya dan remaja akhir (13 sampai 19 tahun) (Murray \& Farrington, 2010). Penelitian yang dilakukan McCoy et al. (2019) menunjukkan bahwa remaja perempuan cenderung lebih mempedulikan penilaian sosial dan menganggap kedekatan relasi pertemanan sebagai sumber dari keberhargaan diri. Secara lebih spesifik, remaja perempuan dinilai lebih sering terpengaruh oleh adanya tekanan negatif dari teman sebaya (Helfert \& Warschburger, 2013). Selain itu, pengalaman merasakan emosi negatif juga lebih sering dan intens terjadi pada remaja perempuan dibandingkan laki-laki (Somerville, Jones, \& Casey, 2010). Karakteristik ini membuat peneliti mengarahkan fokus kepada tekanan teman sebaya yang dialami remaja perempuan.

Selain faktor usia dan jenis kelamin, kondisi sekolah dapat memengaruhi perila$\mathrm{ku}$ remaja yang terpapar tekanan teman sebaya. Sekolah berbasis agama dinilai dapat memberikan dampak positif terhadap perilaku remaja (LeBlanc \& Slaughter, 2012). Nilai-nilai religiusitas dapat membuat remaja semakin memahami nilai yang dianut diri sendiri maupun orang lain. Secara khusus, penelitian terdahulu yang dilakukan di beberapa sekolah berbasis agama Kristiani sudah menunjukkan bahwa para pelajar dapat menyampaikan keinginan dengan lebih terbuka kepada teman-teman mereka (Astill, 1998). Hal ini diduga terkait dengan identitas sekolah dan nilai yang ditanamkan yang berperan sebagai faktor protektif yang menghindari remaja dari kenakalan dan perilaku beresiko (Grier \& Gudiel, 2011). Hasil penelitian lain dari Salas-Wright et al. (2017) mengindikasikan bahwa religiusitas memoderasi hubungan antara faktor resiko dan perilaku berisiko remaja. Religiusitas dapat menjadi pelindung agar remaja mampu menghindari tekanan negatif yang diterima dari lingkungan (Salas-Wright et al., 2017). Melalui hal tersebut, penelitian ini juga akan fokus kepada remaja perempuan yang berasal dari sekolah berbasis agama Kristen atau Katolik untuk melihat pengaruh dari tekanan teman sebaya terhadap perilaku yang ditunjukkan.

Intervensi yang dinilai efektif untuk mencegah remaja menampilkan perilaku menyimpang akibat tekanan negatif oleh teman sebaya adalah dengan meningkatkan kompetensi sosial dan personal. Salah satu bentuk dari kompetensi personal yang dinilai penting adalah kemampuan untuk menolak secara asertif yang umum disebut assertive refusal skill atau ARS (Nichols et al., 2006). Keterampilan menolak akan membuat remaja mampu untuk menghindari tekanan negatif sedangkan asertivitas membantu remaja untuk menyampaikan dengan gaya komunikasi yang tepat. Kedua kemampuan ini penting untuk dikuasai agar remaja mampu terhindar dari perilaku berisiko dan kenakalan remaja, namun tidak merusak hubungan pertemanan yang terjalin. Hasil penelitian Yunalia dan Etika (2019) menunjukkan pelatihan asertivitas dapat meningkatkan gaya komunikasi yang lebih asertif pada remaja dan mengatasi 
masalah perilaku mereka. Mengajarkan strategi-strategi untuk menolak tekanan negatif oleh teman sebaya dengan cara yang asertif merupakan program pencegahan yang efektif untuk menghindari remaja terjerumus ke dalam masalah yang lebih besar (Nichols et al., 2006).

Keterampilan menolak dan asertivitas lebih efektif jika ditingkatkan melalui sesi kelompok seperti pelatihan dibandingkan secara individual. Sesi kelompok seperti pelatihan melibatkan aktivitas sharing dan role-play, sehingga partisipan dapat saling bertukar pikiran (Hosseini et al., 2015). Intervensi kelompok merujuk pada penanganan yang dilakukan terhadap sejumlah individu dengan karakteristik masalah serupa yang bertujuan untuk membantu individu mengatasi permasalahan yang dihadapi individu (Dishion \& Stormshak, 2007; Gidron, 2013). Beberapa kelebihan dari intervensi kelompok adalah individu memiliki kesempatan belajar dari pengalaman partisipan lain, merasa tidak sendirian dalam menghadapi suatu masalah, dan dapat berlatih dalam lingkungan yang aman karena bisa memeroleh umpan balik yang konstruktif (Gidron, 2013).

Dalam penelitian ini, intervensi kelompok berupa pelatihan keterampilan menolak secara asertif dilaksanakan secara daring. Internet-based intervention atau intervensi daring dipandang sebagai metode efektif terhadap penanganan dan pencegahan masalah psikologis (Crisp \& Griffiths, 2014). Lebih lanjut, intervensi daring cocok digunakan pada populasi yang memiliki ketertarikan dengan internet (Crisp \& Griffiths, 2014), salah satunya remaja. Di sisi lain, pelatihan daring menjadi pilihan sehubungan dengan situasi pandemi COVID-19. Remaja tetap memiliki akses internet dimana hal tersebut merupakan salah satu media dalam berkomunikasi sehingga tekanan negatif dari teman sebaya dapat tetap dirasakan. Selain itu, kebijakan pemerintah mengenai pembatasan fisik dan sosial selama PSBB membuat pelatihan daring merupakan salah satu solusi yang sangat mungkin dilakukan.
Berdasarkan latar belakang tersebut, pelaksanaan penelitian ini bertujuan untuk meningkatkan keterampilan menolak dan asertivitas remaja perempuan yang berada di jenjang Sekolah Menengah Pertama (SMP). Setelah mengikuti pelatihan, remaja perempuan diharapkan memiliki kemampuan menolak dan asertivitas yang semakin adekuat, agar semakin mampu mengatasi tekanan negatif yang bertentangan dengan kebijakan pemerintah dalam mengatasi pandemi COVID-19.

\section{Metode}

Penelitian ini menggunakan pendekatan kuantitatif yaitu one group pre-post quasi-experiment design yang bertujuan untuk melihat apakah terdapat peningkatan keterampilan menolak dan asertivitas partisipan setelah mengikuti pelatihan. Keberhasilan pelatihan akan ditentukan melalui 3 indikator yaitu: 1) Partisipan memiliki peningkatan skor keterampilan menolak pada alat ukur Skala Tingkah Laku Asertif aspek Menolak Permintaan (STLA-MP) melalui pretest dan posttest; 2) Partisipan memiliki peningkatan skor gaya komunikasi asertif pada alat ukur Skala Tingkat Perilaku Asertif (STPA) melalui pretest dan posttest; 3) Partisipan merasa semakin mampu menunjukkan keterampilan menolak secara asertif melalui hasil observasi.

\section{Sampel}

Partisipan intervensi adalah pelajar perempuan dari beberapa sekolah swasta Kristen dan Katolik di Jakarta. Partisipan terjaring melalui e-flyer dan google form yang disebarkan secara daring. Melalui pengisian form tersebut, hanya partisipan yang sesuai dengan kriteria dan tujuan penelitian yang terlibat. Pada awalnya, terdapat 22 siswa SMP dari sekolah berbasis Agama Kristen atau Katolik yang mendaftar. Kemudian setelah mengisi melakukan skrining melalui alat ukur PPI dan STLA-MP, diperoleh 5 partisipan yang sesuai dengan kriteria. STPA diukur sebagai 
pretest tetapi tidak sebagai alat skrining.

Kriteria yang digunakan adalah partisipan memiliki skor di bawah rata-rata pada alat ukur STLA-MP, dan menunjukkan tingkat keterpaparan akan tekanan teman sebaya yang berada di atas rata-rata pada alat ukur Peer Pressure Inventory (PPI). Skor di bawah rata-rata pada STLA-MP menunjukkan bahwa partisipan sulit melakukan penolakan. Skor yang tinggi pada PPI mengindikasikan partisipan memiliki tingkat keterpaparan yang tinggi akan tekanan negatif teman sebaya. Pemilihan partisipan bertujuan agar pelatihan dapat diberikan kepada remaja yang benar-benar membutuhkan atau belum menguasai keterampilan yang disasar. Secara umum, kelima partisipan berada pada rentang usia 13 hingga 15 tahun, dimana 2 orang partisipan berada di kelas 8, dan 3 orang lainnya berada di kelas 9 . Hal ini menunjukkan bahwa mereka berada pada tahap perkembangan yang sama dan memiliki karakteristik serupa.

\section{Prosedur}

Pelatihan ini dilakukan secara daring pada masa Pembatasan Sosial Berskala Besar (PSBB) selama pandemi COVID-19. Awalnya, peneliti melakukan analisis kebutuhan pelatihan (training need analysis) dengan melihat fenomena yang terjadi pada lingkungan sekitar. Banyak berita yang menginformasikan bahwa masyarakat sulit mematuhi peraturan pemerintah seperti menjaga jarak dan sosial, menggunakan masker, dan menghindari kerumuman. Peneliti menemukan bahwa pelanggaranpelanggaran tersebut tidak lepas dilakukan oleh remaja.

Tahap selanjutnya adalah menentukan tujuan pelatihan yaitu, partisipan dapat memiliki peningkatan keterampilan menolak secara asertif. Kemudian peneliti mendesain dan mengembangkan sesi pelatihan keterampilan menolak secara asertif menggunakan acuan modul dari Utah Education Network mengenai "refusal skill" (Dickson, 2016). Peneliti melakukan beberapa adap- tasi dan revisi agar sesuai dengan konteks dan kebutuhan pelatihan. Pertama, peneliti mengulas konten dari modul dan disesuaikan dengan karakteristik partisipan. Kemudian, peneliti melakukan expert judgement kepada ahli yaitu psikolog klinis anak dan remaja untuk mengevaluasi modul. Terakhir, peneliti melakukan uji coba modul kepada sejumlah partisipan dengan karakteristik serupa sebelum akhirnya diberikan kepada partisipan utama.

Di dalam modul pelatihan ini, terdapat 5 sesi yang perlu diberikan kepada partisipan. Sesi-sesi tersebut antara lain karakteristik tekanan teman sebaya, tipe-tipe gaya komunikasi, strategi melakukan penolakan, cara melakukan penolakan dengan asertif, serta sesi refleksi dan sharing untuk menemukan insight dari materi yang disampaikan. Dari 5 sesi tersebut, peneliti menggabungkan dua sesi ke dalam satu pertemuan mengingat konten materi pada setiap sesi terbilang singkat (susunan sesi dapat dilihat pada Tabel 1). Selain itu, peneliti juga mengganti contoh skenario dan bentuk contoh perilaku dari materi dan sesi roleplay. Peneliti mengganti skenario dan contoh perilaku yang sesuai dengan situasi pandemi COVID-19, seperti tekanan untuk tidak mematuhi protokol kesehatan dan berkumpul beramai-ramai.

Peneliti menjalankan pelatihan secara daring melalui aplikasi Zoom Meeting. Pelatihan ini terbagi menjadi 3 pertemuan yang dilangsungkan pada tanggal 8,10 , dan 12 Juni 2020. Keterangan lebih lanjut mengenai gambaran kegiatan dapat dilihat pada Tabel 1. Sebelum pelaksanaan sesi, peneliti melakukan uji coba modul untuk mendapatkan gambaran mengenai hal yang sudah baik dan masih perlu ditingkatkan mengenai rincian kegiatan pada setiap sesi.

Dalam setiap sesi pelatihan, peneliti mengimplementasikan daur experiential learning dari Kolb (2015) (Gambar 1). Setiap tahap dalam siklus ini diterapkan pada semua sesi. Concrete experience pada sesi pertama berupa studi kasus, sedangkan pada sesi kedua dalam bentuk permainan. 
Tabel 1. Gambaran Kegiatan Pelatihan

\begin{tabular}{clcc}
\hline $\begin{array}{c}\text { Pert. } \\
\text { Ke- }\end{array}$ & \multicolumn{1}{c}{ Sesi } & Waktu & Durasi \\
\hline & Seputar & & \\
& Tekanan & & 45 menit \\
& Teman & Senin, & \\
1 & Sebaya & 8 Juni & \\
& Mengenal & 2020 & \\
& Gaya & & 45 menit \\
& Komunikasi & & \\
& Strategi & & \\
& Melakukan & Rabu, & 45 menit \\
2 & Penolakan & 10 Juni & \\
& Komunikasi & 2020 & 45 menit \\
& Asertif & Kamis, & \\
& Role play & 11 Juni & 15 menit \\
Latihan & individu & 2020 & \\
& Menemuka & Jumat, & \\
3 & 12 Juni & 60 menit \\
& n Insight & 2020 & \\
& & &
\end{tabular}

Selanjutnya, reflective observation dilakukan setelah kegiatan pada concrete experience. Peneliti mendorong partisipan untuk melakukan refleksi melalui metode debriefing. Peneliti melemparkan pertanyaan pencetus kemudian memberikan kesempatan kepada peserta untuk menjawab. Abstract conceptualization berupa pemaparan materi oleh peneliti kepada setiap partisipan (Kolb \& Kolb, 2013). Kemudian tahap yang terakhir adalah active experimentation yang dalam hal ini partisipan dapat mempraktikkan materi yang diperoleh dalam kegiatan role-play.

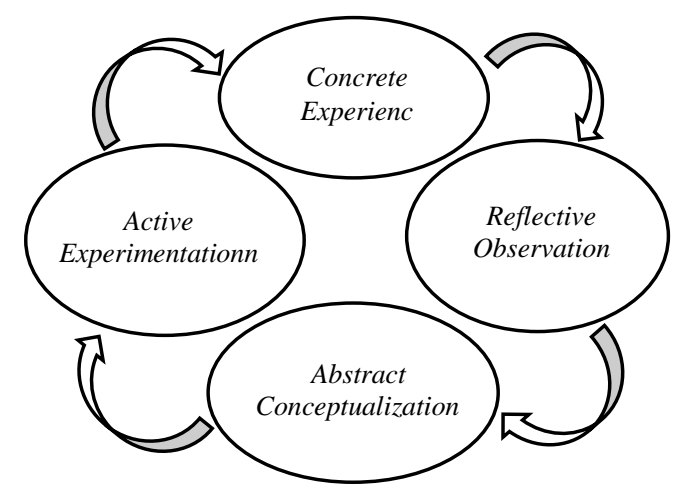

Gambar 1. Daur Experiential Learning (Kolb, 2015)

Secara lebih rinci, pertemuan pertama meliputi pembahasan mengenai tekanan teman sebaya, mulai dari definisi, bentuk, dan contoh-contoh yang umum dijumpai remaja. Selain itu, terdapat pula penjelasan mengenai berbagai macam gaya komunikasi, yaitu pasif, agresif, dan asertif. Peneliti mengadakan sesi role-play di akhir sesi dengan tujuan memberikan kesempatan berlatih mempraktikkan gaya komunikasi yang ideal yakni asertif. Pada pertemuan kedua, materi yang diberikan berupa 5 strategi melakukan penolakan. Sama seperti sesi sebelumnya, peneliti juga memberikan kesempatan berlatih untuk mempraktikkan lima strategi melakukan penolakan kepada partisipan dengan berbagai skenario seputar kondisi pandemi COVID-19.

Pada sesi latihan individu yakni antara pertemuan kedua dan ketiga, peneliti melakukan role-play dengan setiap partisipan berdasarkan sebuah skenario. Saat itu partisipan diminta untuk melakukan penolakan secara asertif. Hasil role-play akan dijadikan poin pembahasan pada sesi ketiga. Terakhir, pada sesi ketiga, peneliti merangkum keseluruhan sesi, melakukan diskusi kelompok, dan menarik insight yang partisipan peroleh selama mengikuti pelatihan.

\section{Pengumpulan Data}

Instrumen yang digunakan pada penelitian ini adalah Peer Pressure Inventory (PPI), Skala Tingkah Laku Asertif - aspek Menolak Permintaan (STLA-MP), dan Skala Tipe Perilaku Asertif (STPA). PPI digunakan sebagai alat skrining partisipan yang dapat mengikuti pelatihan. Partisipan dengan skor PPI yang berada di atas ratarata menunjukkan bahwa mereka memiliki keterpaparan yang tinggi terhadap tekanan dari teman sebaya. Karena itu, partisipan dengan skor PPI yang berada di atas ratarata dinilai lebih rentan dan membutuhkan pelatihan keterampilan menolak dan asertivitas untuk menghadapi tekanan teman sesebaya.

Pertama, peneliti melihat keterpaparan tekanan teman sebaya menggunakan PPI yang disusun oleh Brown \& Clasen (1985) 
dan telah diadaptasi ke dalam bahasa Indonesia. Alat ukur ini terdiri dari 5 dimensi meliputi: 1) peer involvement; 2) school involvement; 3) family involvement; 4) conformity to peer norms; 5) misconduct. Tetapi, peneliti hanya menggunakan peer involvement, conformity to peer norms, dan misconduct karena kedua dimensi lainnya kurang relevan dalam penelitian ini. Dengan demikian, terdapat 15 aitem yang diperoleh dari 5 aitem pada setiap dimensi dengan 6 pilihan jawaban yaitu tidak pernah, jarang, agak jarang, agak sering, sering, dan selalu.

Selanjutnya terdapat STLA untuk mengukur tingkah laku asertif. Pada penelitian ini, STLA yang digunakan hanya aspek menolak permintaan (STLA-MP), sesuai dengan tujuan penelitian. Terdapat 5 aitem pada aspek ini, dan responden diminta untuk memilih 1 dari 4 pilihan jawaban yang ada: 1) tidak pernah, 2) jarang, 3) sering, dan 4) selalu. Peneliti melakukan uji validitas dan reliabilitas pada alat ukur ini karena perbedaan karakteristik usia. Berdasarkan hasil pengujian pada 330 responden, diperoleh koefisien reliabilitas 0.814 dan koefisien korelasi sebagai teknik uji validitas yang berkisar dari 0.549 hingga 0.654 . Melalui hasil tersebut, dapat disimpulkan bahwa semua aitem pada STLA-MP adalah reliabel dan valid.

Instrumen ketiga adalah STPA untuk melihat kecenderungan tipe perilaku individu ke dalam tiga kelompok: 1) asertif, 2) non-asertif, 3) agresif. STPA terdiri dari 20 aitem, masing-masing aitem memiliki 3 pilihan jawaban. Setiap jawaban melambangkan tipe komunikasi tertentu yaitu antara agresif, asertif, atau pasif. Peneliti melakukan pengujian reliabilitas dan validitas dan berdasarkan hasil pengujian pada 330 responden, diperoleh koefisien reliabilitas sebesar 0.780 dan koefisien korelasi sebagai teknik uji validitas yang berkisar dari 0.127 hingga 0.451 . Hasil ini menunjukkan bahwa STPA memiliki aitem yang reliabel dan valid.

Pengumpulan data dilakukan secara daring menggunakan google form. Partisi- pan diminta untuk mengisi alat ukur sebelum dan sesudah intervensi sebagai data pretest dan posttest. Kemudian dua minggu setelah sesi ketiga, partisipan diminta kembali mengisi alat ukur sebagai data follow up.

\section{Analisis Data}

Teknik analisis untuk menguji hipotesis penelitian ini ditentukan setelah dilakukan uji normalitas. Hasil uji normalitas menunjukkan bahwa persebaran data terdistribusi secara tidak normal. Karena itu, peneliti menggunakan Wilcoxon Signed Rank Test dengan bantuan IBM SPSS 22.0 for windows untuk melihat apakah ada peningkatan keterampilan menolak dan asertivitas subjek penelitian antara sebelum dan setelah diberikan intervensi.

\section{Hasil}

\section{Hasil Kuantitatif}

Secara umum, pelatihan daring dapat meningkatkan keterampilan perilaku menolak dan asertivitas pada remaja yang dilihat melalui peningkatan skor pada dua instrumen yaitu STLA-MP dan STPA. Berikut merupakan penjabaran data pretest, posttest, dan follow up dari kelima partisipan.

Berdasarkan hasil pengisian kuesioner STLA-MP, tiga dari lima partisipan berinisial MA, ML, dan TH mengalami peningkatan skor yang mengindikasikan bahwa mereka semakin mampu melakukan penolakan terhadap teman sebaya. Setelah intervensi, skor yang diperoleh MA, ML, dan $\mathrm{TH}$ berada di atas rata-rata (total skor $>$ 12) yang artinya keterampilan menolak MA, ML, dan TH dapat dikatakan memadai. Secara khusus untuk MA dan ML, terjadi peningkatan skor juga pada saat sesi follow up. Di sisi lain, tidak terdapat perubahan skor pada diri MJ sebelum dan setelah mengikuti pelatihan. Kemudian $\mathrm{CO}$ menunjukkan penurunan 3 skor pada posttest, namun kembali naik 1 skor saat follow up. Perbandingan total skor sebelum inter- 
vensi (pre-test) dan setelah intervensi baik posttest maupun follow up dapat dilihat pada Gambar 2.

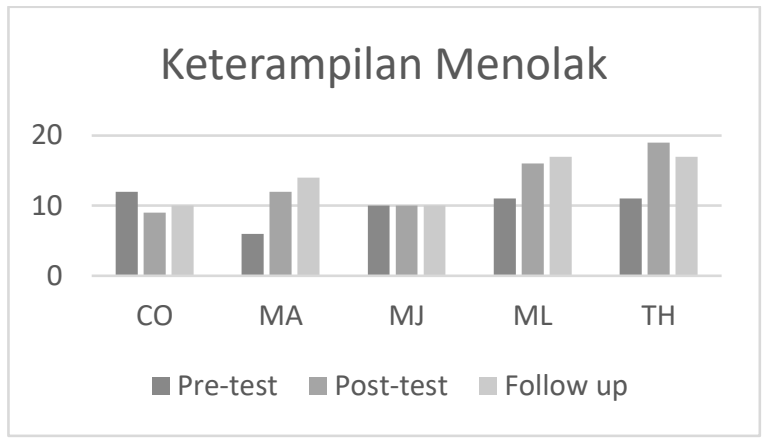

Gambar 2. Hasil pretest, posttest, dan follow up pada STLA-MP

Berikutnya, hasil pengisian kuesioner STPA menunjukkan bahwa seluruh partisipan mengalami peningkatakan skor pada kecenderungan gaya komunikasi asertif. Artinya, partisipan semakin mampu mengetahui dan menerapkan gaya komunikasi asertif dalam kehidupan sehari-hari. Perbandingan skor sebelum intervensi (pretest) dan setelah intervensi baik posttest maupun follow up dapat dilihat pada Gambar 3.

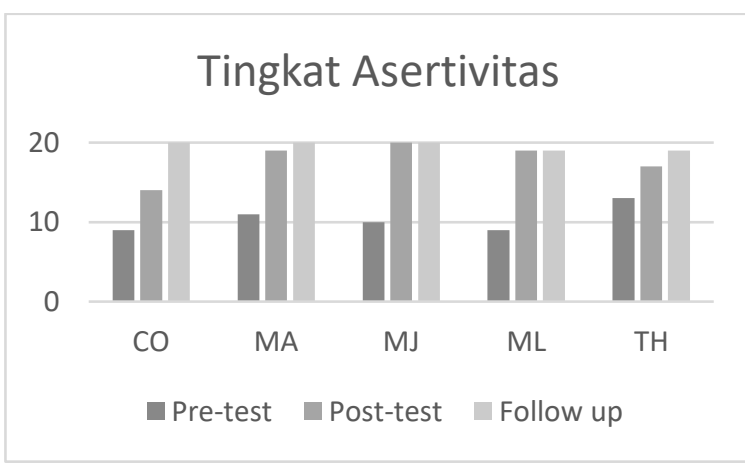

Gambar 3. Hasil pretest, posttest, dan follow up pada STPA

Berdasarkan hasil pengolahan data, dapat terlihat bahwa 3 dari 5 partisipan mengalami peningkatan skor keterampilan menolak dan seluruh partisipan mengalami peningkatan skor untuk gaya komunikasi asertif. Namun, diperlukan pengujian lebih lanjut untuk melihat signifikansi peningkatan tersebut. Distribusi data keterampilan menolak dan gaya komunikasi partisipan sebelum dan setelah pelatihan memiliki signifikansi Shapiro-Wilk lebih dari 0.05 ( $>0.05$ ), sehingga dapat dikatakan bahwa skor tidak terdistribusi secara normal. Hal ini mengarahkan kepada pengujian selanjutnya menggunakan Wilcoxon SignedRank Test. Berikut merupakan hasil dari pengujian Wilcoxon Signed-Rank Test (Tabel 2).

Data pada tabel 2 menunjukkan bahwa peningkatan skor pada STLA-MP sebelum dan setelah intervensi tidak signifikan karena memiliki nilai signifikansi lebih dari $0.05(\mathrm{p}<0.05)$. Artinya, pelatihan daring yang diberikan belum memberikan dampak yang signfikan kepada partisipan untuk dapat menguasai keterampilan menolak. Di sisi lain, peningkatan skor pada STPA sebelum dan setelah intervensi mengalami peningkatan yang signifikan, ditunjukkan dengan nilai signifikansi kurang dari 0.05 $(p<0.05)$. Artinya, pelatihan daring dapat membuat partisipan semakin menguasai gaya komunikasi asertif secara signifikan. Dengan demikian, dapat disimpulkan bahwa secara kuantitatif pelatihan daring ini belum berhasil meningkatkan keterampilan menolak secara signifikan, tetapi mampu meningkatkan kecenderungan gaya komunikasi asertif secara signfikan pada partisipan dalam menghindari tekanan negatif dari teman sebaya

Tabel 2. Hasil Uji Signifikansi Perbedaan Skor Sebelum dan Setelah Intervensi

\begin{tabular}{ll}
\hline \multicolumn{1}{c}{ Alat ukur } & Sig \\
\hline $\begin{array}{l}\text { Keterampilan Menolak } \\
\text { (STLA-MP) }\end{array}$ & .197 \\
Komunikasi Asertif (STPA) & $.042 *$ \\
\hline * $<0.005$ &
\end{tabular}

\section{Hasil Kualitatif}

Pada pertemuan pertama, seluruh partisipan dapat memahami pengertian dari tekanan teman sebaya dan menyadari bahwa hal tersebut mereka rasakan di kehidupan keseharian, termasuk saat masa PSBB. Setiap partisipan memiliki pengalaman yang berbeda-beda terkait tekanan 
teman sebaya sehingga respon yang diberikan pun beragam. Ada partisipan yang dapat memikirkan konsekuensi dari melakukan sebuah pengaruh negatif, namun ada yang cenderung langsung mengikuti pengaruh karena takut dijauhi atau merasa sungkan (tidak enak). Pada akhirnya partisipan lebih sering mengatakan "ya" kepada pengaruh yang diberikan teman padahal sebenarnya ingin berkata "tidak".

Pada saat sesi role-play di Zoom breakout rooms, gaya komunikasi yang ditunjukkan oleh partisipan masih cukup beragam. Tiga orang partisipan menunjukkan keraguan ketika mendapat tekanan negatif dari teman sebaya dan masih menggunakan gaya komunikasi pasif. Mereka terlihat bingung dan ragu untuk menolak ajakan yang diberikan teman, misalnya saat diajak pulang larut malam padahal tidak diperbolehkan orang tua. Kemudian dua orang partisipan lainnya sudah dapat menggunakan gaya komunikasi asertif dengan menyertakan alasan yang logis. Mereka dapat menggunakan bahasa yang sopan dan mudah dipahami.

Pada pertemuan kedua, seluruh partisipan sudah berusaha menerapkan 5 langkah melakukan penolakan. Partisipan dapat menyebutkan kelima langkah tersebut yaitu bertanya, menentukan masalah, memberitahu konsekuensi, menyampaikan alternatif, dan pergi menghindari tekanan negatif. Selain itu, pada materi gabungan mengenai cara menolak dengan gaya komunikasi asertif, setiap partisipan dapat mengelaborasi kedua materi dengan cukup baik. Setiap partisipan dapat menjelaskan ciriciri gaya komunikasi asertif dan menghindari penerapan melakukan penolakan dengan pasif atau agresif. Mereka mampu menyampaikan pertimbangan menolak kepada lawan bicara dan mencari jalan tengah dalam meresponi pengaruh dari teman sebaya.

Pada sesi role-play, empat orang partisipan dapat mempraktikkan 5 langkah melakukan penolakan dengan asertif. Seluruh langkah disampaikan dengan runut, tanpa ada yang terlewat. Namun, ada satu orang partisipan yang sempat melewati tahap pemberian alternatif karena merasa kesulitan untuk memunculkan ide yang dapat diberikan sebagai pengalih. Langkah kelima baru digunakan saat partisipan semakin diberikan tekanan untuk mengikuti ajakan negatif. Tiga partisipan masih terlihat mencari-cari alasan untuk pergi, dimana alasan tersebut sebenarnya tidak benarbenar mereka rasakan. Berbeda dengan ketiganya, dua orang partisipan memutuskan untuk pergi dengan mengatakan "Kalau tetap mau pergi beramai-ramai, kamu saja. Tetapi aku tetap tidak ikut”.

Pada sesi role-play individu, kelima partisipan menunjukkan respon yang bervariasi. Tiga orang partisipan cenderung memberikan respon spontan dan tidak terlalu memperhatikan urutan 5 langkah melakukan penolakan, sedangkan kedua partisipan lainnya memberikan respon yang sesuai dengan urutan yang tepat. Dalam mempraktikkan 5 langkah melakukan penolakan tersebut, setiap partisipan membutuhkan waktu yang cukup berbeda-beda. Mereka terlihat masih membutuhkan proses latihan agar dapat melakukan penolakkan dengan lancar.

Berdasarkan konten yang diucapkan, partisipan sudah mampu memberikan kalimat penolakan yang asertif. Pertanyaan yang dilontarkan biasanya berupa kalimat probing karena bertujuan menggali informasi lebih lanjut seperti "Kenapa harus melakukan itu? Emangnya buat apa?”. Partisipan tampak masih kesulitan memberikan label masalah pada ajakan yang diberikan. Selanjutnya, kelima partisipan sudah mampu menyatakan konsekuensi, baik konsekuensi bagi dirinya sendiri maupun orang lain. Pada bagian alternatif, empat orang partisipan mampu memberikan alternatif yang setara yaitu mengajak teman untuk membuat konten yang positif, sedangkan satu partisipan lainnya sempat melewatkan bagian pemberian alternatif. Kelima partisipan dapat menunjukkan respon pergi dengan asertif saat PI tetap berusaha memaksa mereka mengikuti ajakan teman sesuai dengan skenario yang dibe- 
rikan.

Pada pertemuan ketiga, secara umum partisipan dapat menunjukkan sikap yang kooperatif, namun dengan tingkat partisipasi yang cukup beragam. Setiap partisipan sempat mengangkat tangan untuk menjawab pertanyaan maupun memberikan kesan selama mengikuti pelatihan ini. Dua orang partisipan dapat menjelaskan definisi dan bentuk dari peer pressure. Kemudian tiga orang lainnya menjelaskan berbagai tipe gaya komunikasi, dan 5 langkah melakukan penolakkan.

Setiap partisipan memberikan kesan terhadap pelatihan daring ini. Partisipan 1 menyampaikan ia menyadari bahwa setiap orang berhak untuk menolak, meskipun sejauh ini perasaan bersalah masih kuat dirasakan saat akan menolak ajakkan orang lain. Partisipan 2 menyampaikan bahwa pelatihan ini membuatnya semakin berani untuk menolak pengaruh negatif dari teman sebaya. Kemudian, partisipan 3 tetap merasa kesulitan untuk melakukan penolakan. Ia masih sering merasa sungkan dan kesulitan untuk berkata tidak, terlebih karena ia belum memiliki kesempatan berlatih yang cukup. Selanjutnya, partisipan 4 menyatakan bahwa sebelumnya pelatihan ia sering merasa bersalah dan sulit untuk menolak, namun setelah pelatihan ia sama sekali tidak merasa bersalah dan kesulitan menolak permintaan teman yang tidak ingin ia lakukan. Terakhir, partisipan 5 mengaku bahwa materi pelatihan membuatnya menyadari bahwa ia perlu mengutamakan perasaannya juga dan tidak apa untuk menolak.

\section{Pembahasan}

Setelah memberikan pelatihan keterampilan menolak dan asertivitas pada 5 remaja perempuan di Jakarta, dapat disimpulkan bahwa kedua keterampilan tersebut mengalami peningkatan. Akan tetapi, peningkatan secara signifikan hanya terjadi pada aspek asertivitas, sedangkan keterampilan menolak tidak meningkat secara signifikan. Hal ini diduga disebabkan oleh minimnya kesempatan untuk melatih keterampilan menolak sehingga membuat partisipan belum sepenuhnya yakin akan kemampuan yang sedang dipelajari. Terbatasnya kesempatan berlatih disebabkan oleh adanya kebijakan melakukan karantina dan sekolah secara daring di rumah. Selain itu, partisipan mengakui bahwa biasanya tekanan teman sebaya lebih kuat dirasakan saat mereka melakukan pertemuan tatap muka. Pengaruh teman sebaya terjadi karena adanya pengaruh timbal balik dari dua pihak atau lebih melalui komunikasi atau interaksi (Suwarna, 2005). Saat interaksi langsung secara tatap muka dibatasi, maka tekanan teman sebaya dirasakan lebih minimal (Harakeh \& Vollebergh, 2012). Partisipan juga menyatakan bahwa belajar dari rumah dan selalu berada di sekitar keluarga membuat mereka terlindungi dari tekanan teman sebaya sehingga dapat menghindari berbagai perilaku berisiko. Meskipun tekanan teman sebaya merupakan prediktor terkuat dalam perilaku penyimpangan remaja, namun lingkungan keluarga memberikan efek perlindungan dari perilaku penyimpangan itu (Sullivan, 2006).

Tiga dari lima partisipan menunjukkan peningkatan skor pada STLA-MP, satu partisipan memiliki nilai yang sama, dan satu partisipan lainnya mengalami penurunan. Pada partisipan yang mengalami peningkatan, mereka mengaku lebih mampu melakukan penolakan karena mengetahui alasan yang mendorong mereka mengambil keputusan demikian. Steinberg dan Monahan (2007) menyatakan bahwa seberapa berpengaruh tekanan teman sebaya terhadap diri seorang remaja tidak lepas dari kedalaman nilai yang dianut, sehingga jika remaja yakin akan suatu nilai tertentu mereka akan lebih mampu terhindar dari pengaruh negatif. Salah satu alasan yang disampaikan adalah mereka tahu bahwa ajakkan yang diterima bersifat negatif dan tidak ingin terkena dampak yang akan merugikan dirinya. Remaja yang terpengaruh tekanan teman sebaya bisa disebabkan oleh bentuk loyalitas terhadap kelompok atau karena ingin memiliki kesamaan nilai dengan ke- 
lompok (Michael \& Ben-Zur, 2007). Skor yang sama atau bahkan menurun dikarenakan partisipan memiliki perasaan yang kuat untuk menyenangkan teman mereka. Hal ini sesuai dengan penelitian Allen dan Brown (2008) bahwa kesulitan menolak juga dapat dipengaruhi oleh adanya perasaan ingin menyenangkan anggota kelompok.

Selain STLA-MP, peningkatan juga terjadi pada STPA. Dalam hal ini, seluruh partisipan mengalami peningkatan skor pada gaya komunikasi asertif. Artinya, seluruh partisipan semakin mampu menyampaikan pendapat tanpa menyakiti orang lain. Peningkatan juga terjadi dari sesi posttest ke sesi follow-up. Hal ini menunjukkan bahwa waktu berlatih dan mengendapkan materi yang diperoleh membuat partisipan semakin meningkatkan kemampuan berbicara dengan asertif.

Keberadaan sesi role-play membuat peserta memiliki kesempatan dan pengalaman untuk menerapkan materi yang telah dipelajari pada sesi sebelumnya. Seluruh partisipan dapat menerapkan gaya komunikasi asertif serta 5 langkah melakukan penolakan meskipun ada tahap yang dirasa masih sulit. Seluruh partisipan dapat memberikan jawaban yang sesuai dan terlihat bahwa dinamika di dalam sesi roleplay lebih baik dibandingkan sesi klasikal. Sejalan dengan yang disampaikan Graham et al (dalam Nichols et al, 2010; Venter \& Uys, 2019) bahwa metode role-play cocok dan efektif digunakan untuk melihat perubahan perilaku partisipan dibanding-kan hanya pengisian kuesioner secara individu.

Hasil role-play dan diskusi bersama partisipan menunjukkan bahwa tema mengenai perasaan bersalah ketika melakukan penolak muncul secara konsisten, terutama bagi CO. Hal ini sesuai dengan hasil penelitian dari Bybee (1998) bahwa remaja perempuan lebih sering untuk merasa bersalah dan perasaan tersebut juga memiliki intensitas yang lebih tinggi. Perasaan bersalah yang dimiliki CO muncul karena ia memikirkan perasaan orang lain dan bahkan dapat mendorongnya untuk meminta maaf kepada orang lain. Lebih lanjut,
Bybee (1998) juga menyatakan bahwa perasaan bersalah pada remaja perempuan biasanya bersumber dari masalah relasi dengan orang tua atau teman.

Sedikit berbeda dengan CO, perasaan yang sering muncul adalah sungkan atau merasa "tidak enak". Perasaan ini muncul ketika partisipan akan melakukan penolakan karena cemas akan membuat lawan bicara merasa tidak nyaman (Venter \& Uys, 2019). Penelitian menunjukkan bahwa remaja dengan tingkat kecemasan yang tinggi akan lebih mengikuti arahan kelompok (Santrock, 2012). Persamaan dari perasaan sungkan dan bersalah adalah keduanya sama-sama khawatir akan menyinggung perasaan orang lain. Akan tetapi, merasa bersalah akan membuat individu menyalahkan dirinya dan berusaha meminta maaf sedangkan perasaan sungkan membuat individu beranggapan bahwa mereka jangan menyakiti orang lain. Pada umumnya, remaja perempuan dinyatakan lebih sulit menolak karena mereka mengembangkan perasaan ingin tergabung ke dalam suatu kelompok dan takut ditinggalkan yang lebih tinggi dibandingkan laki-laki (Steinberg \& Monahan, 2007). Remaja perempuan cenderung lebih membutuhkan penerimaan dan keintiman pada relasi pertemanan mereka (Allen \& Brown, 2008).

Meskipun dengan sampel yang terbilang sedikit dibandingkan populasi siswa di sebuah sekolah berbasis agama Kristen atau Katolik pada umumnya, data PPI menunjukkan bahwa siswa yang berada di sekolah berbasis Agama Kristen atau Katolik pun tidak dapat terhindarkan dari tekanan teman sebaya. Bahkan, mereka dapat memiliki keterpaparan yang tinggi akan tekanan teman sebaya. Dengan kata lain, tekanan teman sebaya merupakan hal yang sangat umum dijumpai pada remaja. Temuan ini sejalan dengan hasil penelitian Grier dan Gudiel (2011) yang melaporkan bahwa sekolah dengan nilai Kristiani merupakan faktor protektif yang dapat menghindari remaja dari perilaku berisiko dan kriminal. Selain itu, penelitian lain juga menyatakan hasil serupa bahwa nilai agama berperan besar 
dalam menghindarkan para murid dari perilaku berisiko (Yonker et al., 2012). Nilainilai religius yang ditanamkan pada remaja dapat menjadi pelindung agar mereka tidak mengambil tindakan berisiko (Hardy et al., 2019).

\section{Simpulan}

Berdasarkan hasil penelitian dapat disimpulkan bahwa pelatihan yang telah dilakukan ini dapat meningkatkan keterampilan menolak dan asertivitas pada remaja berbasis agama Kristiani. Secara khusus, pelatihan ini secara signifikan dapat meningkatkan gaya komunikasi asertif, tetapi peningkatan keterampilan menolak tidak signifikan. Oleh karena itu, pelatihan keterampilan menolak dan asertivitas dapat dikatakan penting diberikan kepada para remaja dan sangat memungkinkan untuk diberikan secara daring.

\section{Saran}

Penelitian ini memiliki beberapa keterbatasan yang perlu diatasi oleh peneliti selanjutnya. Pertama, perlu memperbanyak kesempatan bagi para partisipan untuk melatih keterampilan menolak. Karantina di rumah dan pembelajaran jarak jauh membuat interaksi partisipan dengan teman sebaya menjadi lebih terbatas. Hal ini dapat diakomodir dengan menciptakan role-play antar sesama partisipan dengan memanipulasi lingkungan sehingga tampak seperti lingkungan asli partisipan.

Kemudian, pelatihan ini baru diujikan pada remaja perempuan di Jakarta yang berasal dari sekolah berbasis Kristiani, sehingga belum diketahui efektivitasnya pada karakteristik yang berbeda. Karena itu, penelitian selanjutnya dapat menerapkan program serupa kepada remaja dengan cakupan yang berbeda, misalnya jenis kelamin laki-laki dan jenis sekolah umum.

\section{Daftar Pustaka}

Allen, J. P., \& Brown, B. B. (2008). Adolescents, peers, and motor vehicles: the perfect storm? American journal of preventive medicine, 35(3), S289-S293.

https://doi.org/10.1016/j.amepre.2008 .06 .017

Astill, B. (1998). Yes! Christians are Different; but are Their Schools? Journal of Christian Education, (2), 27-44. https://doi.org/10.1177/00219657980 4100204

Badan Pusat Statistik (BPS). (2012). Survei demografi dan kesehatan Indonesia 2012. Kesehatan Reproduksi remaja. Jakarta: Kementerian Kesehatan Jakarta.

http://www.bkkbn.go.id/litbang/pusd u/Hasil\%20Penelitian/SDKI\%20201 2/Laporan\%20Pendahuluan\%20REM AJA \%20SDKI\%202012.pdf
Brown, B.B., Clasen, D.R. \& Eicher, S.A. (1986). Perceptions of peer pressure, peer conformity dispositions, and self-reported behavior among adolescents. Developmental Psychology, 22(4), 521-530. https://doi.org/10.1037/00121649.22.4.521

Brown, B. B., Bakken, J. P., Ameringer, S. W., \& Mahon, S. D. (2008). A comprehensive conceptualization of the peer influence process in adolescence. In M. J. Prinstein \& K. A. Dodge (Eds.), Duke series in child development and public policy. Understanding peer influence in children and adolescents (p. 17-44). The Guilford Press.

Bybee, J. (1998). The emergence of gender differences in guilt during adolescence. Guilt and children. Academic Press. 
CNBC Indonesia (2021, April 25). Update Corona 25 April, Kasus Tambah 4.402, DKI-Jabar Teratas. https://www.cnbcindonesia.com/new s/20210425163234-4-

240679/update-corona-25-aprilkasus-tambah-4402-dki-jabar-teratas

Crisp, D. A., \& Griffiths, K. (2014). Participating in online mental health interventions: Who is most likely to sign up and why? Depression Research and Treatment, 2014, 1-11. https://doi.org/10.1155/2014/790457

Dahl, R. E., \& Spear, L. P. (2004). Adolescent brain development: Vulnerabilities and opportunities (Vol. 1021). New York Academy of Sciences.

Dickson, S. (2016). Utah's Safe and DrugFree Schools and Communities PK12 Prevention Program. Utah State Board of Education.

Dishion, T. J., Andrews, D. W., \& Crosby, L. (1995). Antisocial boys and their friends in early adolescence: Relationship characteristics, quality and interactional process. Child Development, 66, 139-151. https://doi.org/10.1111/j.14678624.1 995.tb00861.x.

Dishion, T. J., \& Stormshak, E. A. (2007). Intervening in children's lives: An ecological, family-centered approach to mental health care. American Psychological Association.

Dodge, K. A., Lansford, J. E., \& Dishion, T. J. (2006). The Problem of Deviant Peer Influences in Intervention Programs. Guildford Publications.

Farrell, A. D., Thompson, E. L., \& Mehari, K. R. (2017). Dimensions of peer influences and their relationship to adolescents' aggression, other problem behaviors and prosocial behavior. Journal of Youth and Adolescence, 46(6), 1351-1369. https://doi.org/10.1007/s10964-0160601-4

Forbes, E. E., \& Dahl, R. E. (2010). Pubertal development and behavior: hormonal activation of social and motivational tendencies. Brain and cognition, 72(1), 66-72. https://doi.org/doi:10.1016/j.bandc.2 009.10.007

Gidron, Y. (2013). Group therapy/intervention. In M. D. Gellman, \& J. R. Turner. (Eds.) Encyclopedia of Behavioral Medicine (pp.1852-1856). Springer

Grier, L., \& Gudiel, W. (2011). Can religious beliefs combat negative peer influence during adolescence? Mental Health, Religion \& Culture, 14(10), 983-997. https://doi.org/10.1080/13674676.20 10.542452

Hardy, S. A., Nelson, J. M., Moore, J. P., \& King, P. E. (2019). Processes of Religious and Spiritual Influence in Adolescence: A Systematic Review of 30 Years of Research. Journal of Research on Adolescence, 29(2), 254-275.

https://doi.org/10.1111/jora.12486

Hall, K. R., Rushing, J. L., \& Khurshid, A. (2011). Using the Solving Problems Together psychoeducational group counseling model as an intervention for negative peer pressure. The Journal for Specialists in Group Work, 36(2), 97-110. https://doi.org/10.1080/01933922.20 11.562344

Helfert, S., \& Warschburger, P. (2013). The face of appearance-related social pressure: gender, age and body mass variations in peer and parental pressure during adolescence. Child and Adolescent Psychiatry and Mental Health, 7(1), 1-11. https://doi.org/10.1186/1753-20007-16 
Harakeh, Z., \& Vollebergh, W. A. (2012). The impact of active and passive peer influence on young adult smoking: An experimental study. Drug and alcohol dependence, 121(3), 220223.

https://doi.org/10.1016/j.drugalcdep. 2011.08.029

Hosseini, S. A., Mirnasab, M., Salimy, H., $\&$ Zangiabadi, M. (2015). The effect of assertiveness skills training on reduction of emotional victimization of female high school students. International Journal of Life Sciences, 9(4), 59-64. https://doi.org/10.3126/ijls.v9i4.126 79

Kolb, A. Y., \& Kolb, D. A. (2013). The Kolb Learning Style Inventory 4.0: A Comprehensive Guide to the Theory, Psychometrics, Research on Validity and Educational Applications. www.haygroup.com/leadershipandta lentondemand

Kolb, D. A. (2015). Experiential Learning: Experience as the Source of Learning and Development. Pearson Education, NA.

LeBlanc, P., \& Slaughter, P. (2012). Growing thinking Christians: An investigation of the outcomes of Christian education. Journal of School Choice, 6(1), 62-81. https://doi.org/10.1080/15582159.20 12.650087

Loke, A. Y., Mak, Y. W., \& Wu, C. S. T. (2016). The association of peer pressure and peer affiliation with the health risk behaviors of secondary school students in Hong Kong. Public Health, 137, 113123. https://doi.org/10.1016/j.puhe.2 016.02.024

McCoy, S. S., Dimler, L. M., Samuels, D. V., \& Natsuaki, M. N. (2019). Adolescent susceptibility to deviant peer pressure: Does gender matter? Adolescent research review, 4(1), 59-71. https://doi.org/ 10.1007/s40894-017-0071-2

Michael, K., \& Ben-Zur, H. (2007). Risktaking among adolescents: Associations with social and affective factors. Journal of adolescence, 30(1), 17-31. https://doi.org/10.1016/j.adolescence .2005.03.009

Murray, J., \& Farrington, D. P. (2010). Risk factors for conduct disorder and delinquency: key findings from longitudinal studies. The Canadian Journal of Psychiatry, 55(10), 633642.

https://doi.org/10.1177/0706743710 05501003

Nichols, T. R., Graber, J. A., Brooks-Gunn, J., \& Botvin, G. J. (2006). Ways to say no: refusal skill strategies among urban adolescents. American Journal of Health Behavior, 30(3), 227-236. https://doi.org/10.5555/ajhb.2006.30. 3.227

Salas-Wright, C. P., Vaughn, M. G., Maynard, B. R., Clark, T. T., \& Snyder, S. (2017). Public or private religiosity: Which is protective for adolescent substance use and by what pathways? Youth \& Society, 49(2), 228-253. https://doi.org/10.1177/0044118X14 531603

Santrock, J, W. (2012). Perkembangan Anak. Jilid 1. Edisi Kesebelas. Erlangga

Saputri, M, \& Taher, A., P. (2020, Maret 23). Pemerintah Ubah Istilah Social Distancing Jadi Physical Distancing. www.tirto.id/pemerintah-ubah istilah social-distancing-jadi-physical distancing-eG8j

Somerville, L. H., Jones, R. M., \& Casey, B. J. (2010). A time of change: behavioral and neural correlates of adolescent sensitivity to appetitive 
and aversive environmental cues. Brain and cognition, 72(1), 124-133. https://doi.org/10.1016/j.bandc.2009. 07.003

Steinberg, L. (2008). A social neuroscience perspective on adolescent risk-taking. Developmental review, 28(1), 78106. https://doi.org/10.1016/j.dr.2007.08. 002

Sullivan, C. J. (2006). Early adolescent delinquency: Assessing the role of childhood problems, family environment, and peer pressure. Youth violence and juvenile justice, 4(4), 291-313. https://doi.org/10.1177/1541204006 292656

Wilson, R. F., Sharma, A. J., Schluechtermann, S., Currie, D. W., Mangan, J., Kaplan, B., ... \& Gieryn, D. (2020). Factors influencing risk for COVID-19 exposure among young adults aged 18-23 yearsWinnebago County, Wisconsin, March-July 2020. Morbidity and Mortality Weekly Report,69(41), 1497.

http://dx.doi.org/10.15585/mmwr.m m6941e2

Yonker, J. E., Schnabelrauch, C. A., \& DeHaan, L. G. (2012). The relationship between spirituality and religiosity on psychological outcomes in adolescents and emerging adults: A meta-analytic review. Journal of adolescence, 35(2), 299-314. https://doi.org/10.1016/j.adolescence .2011 .08 .010

Yüksel-Şahin, F. (2015). Predicting Peer Pressure Levels Among Turkish Adolescents. Procedia-Social and Behavioral Sciences, 191, 18071812.

https://doi.org/10.1016/j.sbspro.2015 .04 .413

Yunalia, E. M., \& Etika, A. N. (2019). Efektivitas terapi kelompok assertiveness training terhadap kemampuan komunikasi asertif pada remaja dengan perilaku agresif. Jurnal Keperawatan Jiwa, 7(3), 229-236. https://doi.org/10.26714/jkj.7.3.2019 $.229-236$

Venter, E., \& Uys, H. (2019). Group therapy for early adolescent relationship problems between girls. International Journal of Adolescence and Youth, 24(2), 212-223. https://doi.org/10.1080/02673843.20 18.1509794 